\title{
Development of Coagulation Regulatory Proteins in the Fetal and Neonatal Lamb
}

\author{
MARILYN J. MANCO-JOHNSON, LINDA J. JACOBSON, MICHELE R. HACKER, \\ SUSAN F. TOWNSEND, JAMES MURPHY, AND WILLIAM HAY, JR \\ Department of Pediatrics, University of Colorado Health Sciences Center, Aurora, CO, U.S.A. [M.J.M.-J., \\ L.J.J., M.R.H., S.F.T., W.H.]; The National Jewish Hospital, Denver, CO, U.S.A. [J.M.]
}

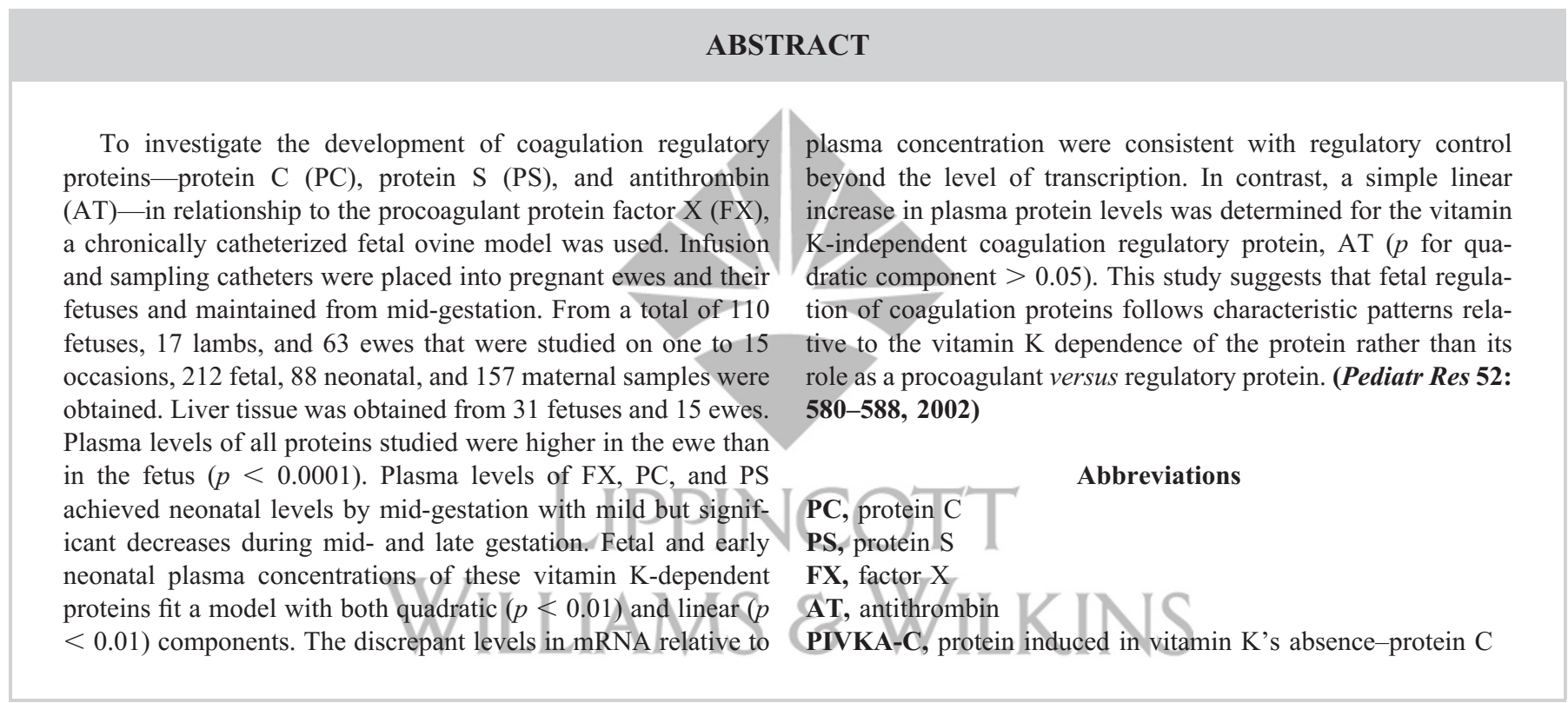

The hemostatic systems of the fetus and neonate differ from that of the adult. Plasma concentrations of coagulation proteins mature at different rates during in utero and postnatal development (1-3). In particular, vitamin K-dependent factors, prothrombin, PC, PS, and factors VII, IX, and X, as well as contact factors XI, XII, prekallikrein, and high-molecular-weight kininogen, are present in very low concentrations in the fetus and do not achieve normal adult levels until later infancy to adolescence (2-7). Clinically, the well neonate has a functionally intact hemostatic system. However, the stressed infant demonstrates an increased predisposition to thrombosis, both induced and spontaneous (8). The increased rate of thrombosis in neonates is generally attributed to physiologically low levels of coagulation regulatory proteins, particularly PC, PS, and AT.

Received August 24, 2001; accepted May 8, 2002.

Correspondence: Marilyn J. Manco-Johnson, M.D., Mountain States Regional Hemophilia and Thrombosis Center, PO Box 6507, Mail Stop F416, Aurora, CO 80045-0507, U.S.A.; e-mail: marilyn.manco-johnson@uchsc.edu

Supported by grants from the National Institutes of Health (HL 44586; DK 35836 to W.W.H.) and the American Diabetes Association (M.M.J.).

DOI: 10.1203/01.PDR.0000030885.86822.AD
$\mathrm{PC}$ is a vitamin $\mathrm{K}$-dependent serine protease that serves a critical role in the regulation of coagulation. Activated PC, with its cofactor PS, inactivates activated procoagulant factors $\mathrm{V}$ and VIII (9). Infants with severe genetic deficiencies of either PC or PS manifest spontaneous thrombosis in utero or within hours of birth $(10,11)$. Our previous work showed that the mean concentration of $\mathrm{PC}$ in the extremely preterm infant is $0.20 \mathrm{U} / \mathrm{mL}$, as compared with $1.00 \mathrm{U} / \mathrm{mL}$ in healthy adults $(6,7)$. An increased risk of catheter-related and spontaneous thrombosis was demonstrated in preterm infants with plasma concentrations of $\mathrm{PC}<0.10 \mathrm{U} / \mathrm{mL}$ (7).

$\mathrm{AT}$ is an essential regulatory protein that functions through inhibition of coagulation serine proteases, including activated factors IX, X, XI, and thrombin (12). The formation of complexes of procoagulant proteins with AT is accelerated 1000fold by heparin (12). Newborn infants have been shown to have approximately $50 \%$ adult plasma concentration of a functionally normal AT $(6,13)$. Heparin resistance, or failure to achieve a plasma anti-Xa activity commensurate with therapeutic heparin infusion rate, is commonly found in infants and ascribed to low neonatal levels of AT (14-16). Complete absence of AT appears to be incompatible with life, as there are 
no infants known to have survived with this condition. In addition, mouse gene "knock-out" models of homozygous AT deficiency show embryonic lethality (17). Heterozygous deficiencies of AT in human infants have been associated with thrombi in the perinatal period $(18,19)$.

To date, it has not been determined whether a biochemical balance exists between procoagulant and anticoagulant proteins during normal fetal development. To prevent or treat bleeding or clotting complications in sick preterm infants, it is necessary to understand physiologic regulation of coagulation proteins during ontogeny. Plasma levels of procoagulant proteins have been studied in various animal models during fetal and neonatal development (20). In contrast, developmental expression of regulatory proteins has not been well studied.

Previous investigations by the authors used a chronically catheterized model of ovine gestation to study molecular forms of PC (21). In that work, fetal ovine plasma PC levels were reported at $25-75 \%$ of nonpregnant, healthy, adult sheep (21). The current studies were designed to meet two objectives. The first was to extend the original observations regarding the development of PC in the stable ovine fetus, neonatal lamb, and pregnant ewe. The second objective was to compare ontogeny of PC with the vitamin K-dependent regulatory protein, PS; the vitamin K-dependent procoagulant protein, $\mathrm{FX}$; and the vitamin K-independent regulatory protein, AT, in the ovine model.

\section{METHODS}

Concentrations of PC, PS, FX, and AT in plasma and abundance of mRNA for PC, PS, and AT in hepatic tissue were determined on samples obtained from a cohort of healthy pregnant ewes, their fetuses, and neonatal lambs. This cohort included samples from animals that were previously reported in a study of molecular structure of fetal ovine PC (21) as well as additional study animals forming a larger cohort. Results of ovine PS, FX, and AT from this ovine cohort have not been previously reported by the authors.

\section{Preparation of the Animal Model}

Columbia-Rambouillet pregnant sheep with known gestational age (from induced ovulation) were operated on between 70 and $120 \mathrm{~d}$ gestation to place maternal arterial sampling and venous infusion catheters or at approximately $120 \mathrm{~d}$ for placement of both maternal and fetal arterial sampling catheters and venous infusion catheters. Surgery was performed using either of two anesthesia protocols: i.v. pentobarbital sedation (15 $\mathrm{mg} / \mathrm{kg}$ ) and spinal anesthesia (tetracaine $\mathrm{HCl}, 10 \mathrm{mg}$ in hypertonic glucose) for the surgery at $120 \mathrm{~d}$ gestation or intramuscular acetylpromazine $(1 \mathrm{mg} / \mathrm{kg})$ with i.v. ketamine anesthesia $(12-15 \mathrm{mg} / \mathrm{kg}$ loading dose with $0.3-0.5 \mathrm{mg} / \mathrm{kg} / \mathrm{min}$ continuous infusion) for the surgery at $70-80 \mathrm{~d}$ gestation. Maternal sampling catheters were placed into the femoral artery and infusion catheters were placed into the femoral vein as previously described $(21,22)$. Fetal catheters were placed via hind limb vessels into the abdominal aorta and the left hepatic vein for sampling and into the inferior vena cava for infusion, as previously described $(21,22)$. All catheters were tunneled subcutaneously to exit the mother through a flank incision and kept within a plastic pouch attached to the maternal flank. The catheters were flushed daily to every other day with $0.9 \%$ $\mathrm{wt} / \mathrm{vol} \mathrm{NaCl}$ in $\mathrm{H}_{2} \mathrm{O}$ that contained $30 \mathrm{U} / \mathrm{mL}$ sodium heparin. After surgery, the sheep were allowed to recover at least $4 \mathrm{~d}$ before study. Healthy chronically catheterized pregnant ewes were allowed an ad libitum diet of alfalfa pellets, water, and mineral supplements. All protocols were approved by the Institutional Animal Care and Use Committee of the University of Colorado Health Sciences Center (UCHSC). All animal procedures were conducted at the UCHSC Perinatal Research Center, which is accredited by the National Institutes of Health, the United States Department of Agriculture, and the American Association for the Accreditation of Laboratory Animal Care.

Blood samples were collected from the ewe and her fetus or neonatal lamb on one or more occasions. The catheters were first cleared by removing $3 \mathrm{~mL}$ of blood, and then $0.9 \mathrm{~mL}$ blood samples were drawn into $0.1 \mathrm{~mL}$ of $3.8 \%$ sodium citrate anticoagulant. The samples were centrifuged at $1800 \times g$ for $20 \mathrm{~min}$ at $4^{\circ} \mathrm{C}$. Aliquots of plasma were subsequently frozen at $-70^{\circ} \mathrm{C}$ until the time of assay.

\section{Laboratory Methods}

Assays of plasma protein concentrations. To develop immunologic assays for ovine PC, PS, and FX, the coagulation proteins were purified from normal sheep plasma. Ovine PC was purified using barium chloride precipitation, EDTA elution, ammonium precipitation, and sequential chromatographies over diethylaminoethyl (DEAE) Sepharose, heparin Sepharose, and Blue Sepharose CL-6B as previously described (21).

Ovine plasma FX and PS were purified using the same plasma source and chromatography columns as PC; however, different column eluent fractions were used for the purification. Column fractions were monitored with coagulation assay for factors II, VII, IX, X, and PC as previously described (21). Column fractions for FX were selected by a FX protime-based clotting assay. PS fractions were selected by their relative molecular weights with silver stains of SDS-PAGE. A total of $13010-\mathrm{mL}$ fractions were eluted from the DEAE-Sephadex A50 column with a $1100 \mathrm{~mL} \mathrm{NaCl}$ gradient $(0.175-0.6 \mathrm{M})$. Fractions 60-87 from the DEAE column containing PC, PS, FVII, and FIX were pooled to form DEAE "A." Fractions 88-100 containing PC were pooled to form DEAE "B." As previously described (21), DEAE "B" was further purified on blue Sepharose CL-6B and heparin Sepharose columns. DEAE fractions 105-120 containing FX were pooled to make DEAE "C." DEAE "C" was applied to a 16-mL blue Sepharose column and eluted with $50 \mathrm{~mL} \mathrm{NaCl}$ gradient $(0-2 \mathrm{M})$ into 90 $0.5-\mathrm{mL}$ fractions. Fractions 3-35 were pooled, applied to a 14-mL heparin Sepharose column, and eluted with $0.1 \mathrm{M} \mathrm{NaCl}$ for concentration purposes. Five milliliter fractions were collected and tested for FX. Fractions 65-75 were pooled and used for antibody production. DEAE "A" was applied to a $55-\mathrm{mL}$ blue Sepharose column and eluted with $450 \mathrm{~mL} \mathrm{NaCl}$ gradient $(0.1-4.1 \mathrm{M})$ into $905-\mathrm{mL}$ fractions. Fractions $80-90$ were pooled, applied to a $90-\mathrm{mL}$ heparin Sepharose column, 
and eluted with $800 \mathrm{~mL} \mathrm{NaCl}$ gradient $(0-1 \mathrm{M})$ into $10-\mathrm{mL}$ fractions. After testing, tubes 54-70 were pooled and used for PS antibody production.

Plasma concentrations of ovine PC, PS, and FX were determined using rabbit anti-sheep polyclonal antibodies in a Laurell rocket assay. The proteins were used to immunize New Zealand White rabbits for production of polyclonal antibodies as previously described (22). The resultant antibodies to PC, PS, and FX were partially purified and tested for specificity with the use of overloaded, crossed immunoelectrophoresis gels with ovine plasma, ovine PC, ovine PS, and ovine FX to detect cross-reactivity. The PS measurement was of total PS. AT activity was determined in a chromogenic assay as previously described (22).

Assays to detect vitamin $\mathbf{K}$ deficiency. To estimate carboxylation of ovine $\mathrm{PC}$, an immunologic assay for PIVKA-C was used as previously reported in neonatal lambs (23). In performance of this assay, $0.5 \mathrm{~mL}$ of fetal ovine plasma anticoagulated in $3.8 \%$ sodium citrate was absorbed with $40 \mu \mathrm{L}$ of $1 \mathrm{M} \mathrm{BaCl}_{2}$ to remove normal carboxylated PC. The plasma was mixed and, after incubation for $1 \mathrm{~h}$ at $4^{\circ} \mathrm{C}$, was centrifuged at $3500 \times g$ for $10 \mathrm{~min}$. The supernatant and the starting plasma were subjected to Laurell rocket immunoelectrophoresis using the rabbit anti-sheep ovine PC antibody. PC antigen concentration determined in the supernatant was reported as noncarboxylated PC, and PC antigen concentration determined in the starting plasma was reported as total PC.

Establishment of normal adult and gestational ovine plasma protein concentrations. Separate aliquots of frozen plasma were thawed for assay of PC, PS, FX, and AT. A standard ovine pool was prepared from 26 healthy, nonpregnant adult sheep (19 males and 7 females). Normal adult values for ovine PC, PS, FX, and AT were derived from these individual plasma samples, with the pool mean expressed as 1 $\mathrm{U} / \mathrm{mL}$. Study samples were read against curves constructed using dilutions of the normal ovine pool. Concentrations of coagulation proteins in the healthy ewes, fetuses, and lambs were evaluated over gestation and the neonatal period to determine and compare physiologic changes associated with gestation and the perinatal period.

Determination of $m R N A$ for PC, PS, and AT. Liver tissue was obtained and processed for the purpose of determining abundance of mRNA for PC, PS, and AT as previously described (22). RNA was isolated by the rapid method of Chomczynski and Sacchi (24) and analyzed by Northern blot hybridization. A ${ }^{32}$ P-labeled $900-$ bp bovine cDNA probe was used as previously described (22). Similarly, ${ }^{32} \mathrm{P}$-labed 2.5 and $1.5 \mathrm{kbp}$ bovine cDNA probes were used for PS and AT, respectively. A cDNA probe for ovine FX mRNA was not available.

Northern blot signals were quantified using scanning densitometry and normalized against the housekeeping gene $\beta$-actin. The results were reported as a percentage of a standard prepared using a pool of mRNA extracted from livers obtained from 15 healthy, nonpregnant ewes.

\section{Data Analysis}

A previous publication reported aggregate data regarding mean PC levels in ewes, fetuses, and lambs (21). However, for this study, individual sample points were subjected to further mathematical analyses and compared with similar analyses for PS, FX, and AT.

These data were analyzed using a mixed model that accounted for the fact that there were repeated measures on some of the sheep. The first step of the analysis was to determine whether the levels of PC, PS, and FX antigen, as well as AT activity, differed with respect to the three groups: fetus, lamb, and ewe. If a statistically significant difference $(p<0.05)$ were detected in the initial model, then the second step was to add linear contrasts to the model. The linear contrasts allowed us to determine which pairs (e.g. fetus and lamb, fetus and ewe, and lamb and ewe) were significantly different. The third analytic step was to examine the relationship between gestational age and the level of each of the following: PC, PS, and FX antigen and AT activity. The group of ewes was excluded from this model. Based on the slightly U-shaped pattern of the plots, we tested for significant linear and quadratic components in each of the four models.

\section{RESULTS}

The study included 110 fetuses, 17 lambs, and 63 ewes from which we drew 212 fetal, 88 neonatal, and 157 maternal samples, respectively. Individual animals were studied on one to 15 occasions.

Protein C. Plasma samples from a subset of 15 ovine fetuses, ranging from 125 to $144 \mathrm{~d}$ gestation, were used to assay for noncarboxylated PC. Their plasma PC antigen ranged from 0.26 to $0.70 \mathrm{U} / \mathrm{mL}$. No sample had detectable noncarboxylated PC.

Figure 1 shows PC plasma concentrations in ovine fetuses, lambs, and ewes as a function of postconceptional age. The initial mixed model demonstrated that the levels of PC antigen were statistically significantly different among the three ovine groups. The mean levels of PC antigen among the fetuses, lambs, and ewes were $47.0 \mathrm{U} / \mathrm{dL}, 42.7 \mathrm{U} / \mathrm{dL}$, and $97.4 \mathrm{U} / \mathrm{dL}$, respectively. Using linear contrasts, we determined that the PC antigen levels did not differ significantly between the fetuses and lambs. We previously reported that lamb PC values were significantly lower than fetal levels when a smaller number of samples were analyzed (21). However, both groups had PC antigen levels that were significantly lower relative to the maternal levels $(p<0.0001)$. Given that fetal and lamb values differed from those of the ewes, we created a model to examine PC antigen levels relative to gestational age. Although the mean fetal and lamb levels of PC antigen did not differ, the individual measurements fit a model with linear $(p=0.0074)$ and quadratic $(p<0.0077)$ components that evidenced a decrease in PC antigen as the fetus approached term and an increase in levels after birth.

Protein S. Figure 2 shows PS levels in ovine fetuses, lambs, and ewes as a function of postconceptional age. We used the same analytic methodology for PS as for PC described above; however, the results were slightly different. The model showed 


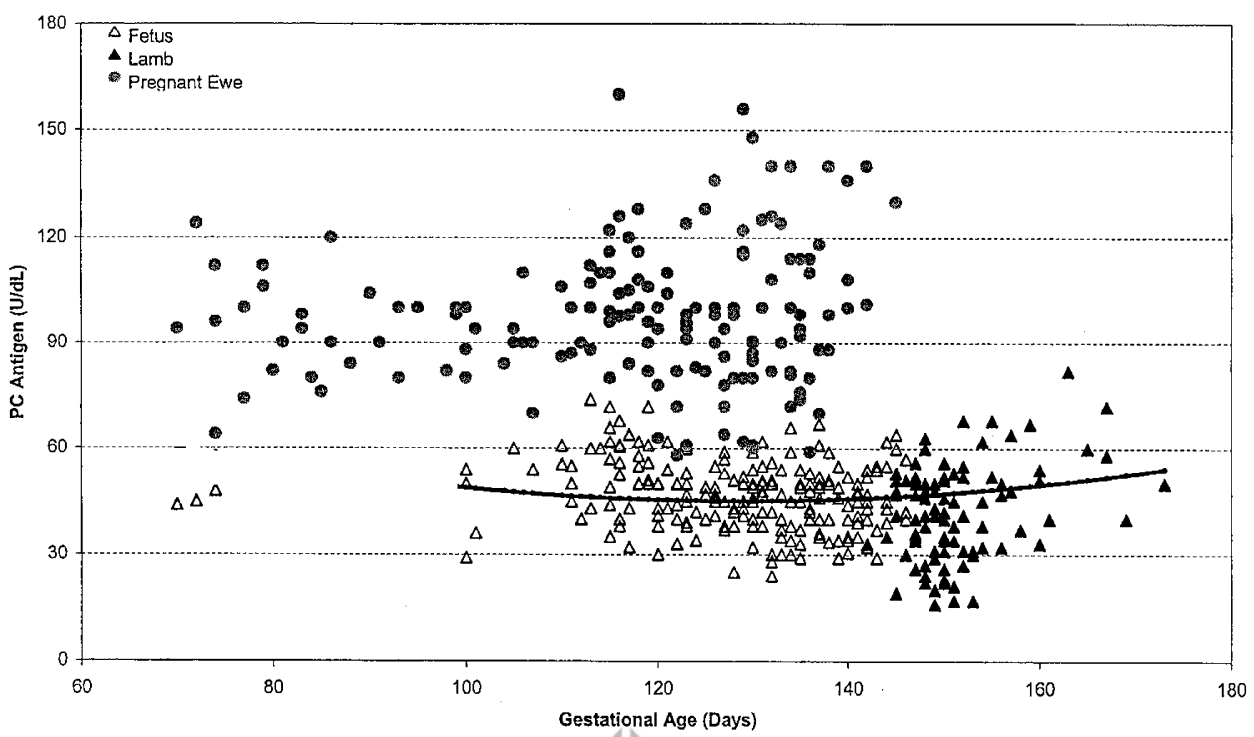

Figure 1. Protein $\mathrm{C}$ antigen in normal ovine fetuses, lambs, and ewes. Plasma concentration of $\mathrm{PC}$ in the ovine fetus, lamb, and pregnant ewe during gestation and postnatal development. Filled circles depict values in ewes; open triangles depict ovine fetal values; and filled triangles represent neonatal lambs after spontaneous delivery at term. Plasma concentration of fetal and neonatal PC antigen shows no gestational increase, and a slight statistical decrease, until close to spontaneous delivery at term. The solid line represents the equation for the model of ovine fetal and lamb PC concentration relative to gestational age. Values in pregnant ewes do not change during gestation.

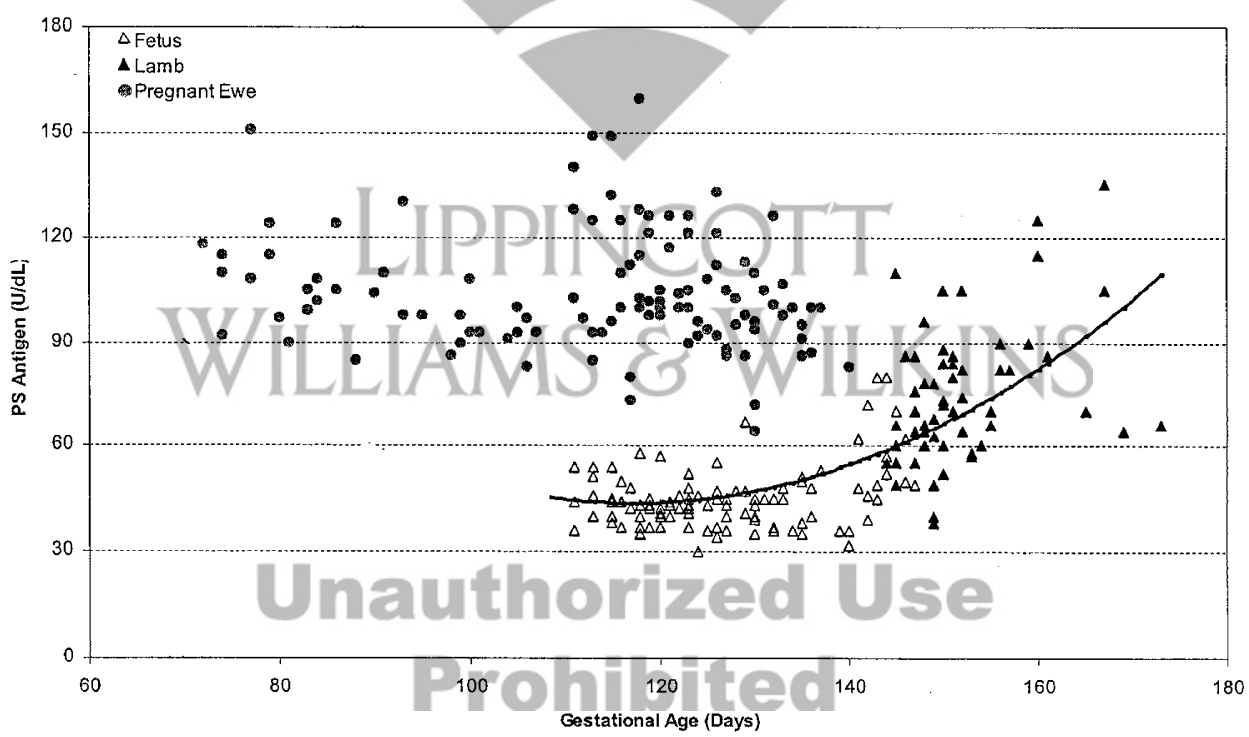

Figure 2. Protein $\mathrm{S}$ antigen in normal ovine fetuses, lambs, and ewes. Plasma concentration of PS in the ovine fetus, lamb, and pregnant ewe during gestation and postnatal development. Filled circles depict values in ewes; open triangles depict ovine fetal values; and filled triangles represent neonatal lambs after spontaneous delivery at term. Plasma concentration of fetal and neonatal PS antigen shows a gestational pattern similar to PC with a steeper increase related to spontaneous delivery at term. The solid line represents the equation for the model of ovine fetal and lamb PS concentration relative to gestational age. Values in pregnant ewes do not change during gestation.

that there were statistically significant differences in PS antigen levels among the three groups. Unlike PC antigen levels, the levels of PS antigen differed among all three pairs of groups ( $p$ $<0.0001$ for each pair). The mean values of PS antigen were $45.6 \mathrm{U} / \mathrm{dL}, 74.4 \mathrm{U} / \mathrm{dL}$, and $104.4 \mathrm{U} / \mathrm{dL}$ for the fetuses, lambs, and ewes, respectively. Similar to PC antigen, the fetal and lamb PS antigen levels also had linear $(p<0.0001)$ and quadratic terms $(p<0.0001)$ relative to gestational age. The model showed a rather dramatic increase in PS antigen that begins just before birth and continues after birth. The data also showed that many of the lamb levels fell within the range of maternal PS antigen.

Factor $X$. Figure 3 shows FX levels in ovine fetuses, lambs, and ewes as a function of postconceptional age. Just as with the PC and PS models, the FX model indicated that the fetal, lamb, and maternal FX antigen levels differed. The mean FX antigen levels were $24.1 \mathrm{U} / \mathrm{dL}$ for fetuses, $44.9 \mathrm{U} / \mathrm{dL}$ among lambs, and 108.2 U/dL for ewes. Again, linear contrasts supported that the apparent differences between these mean levels were statistically significant ( $p<0.0001$ for each pair of groups). Relative 


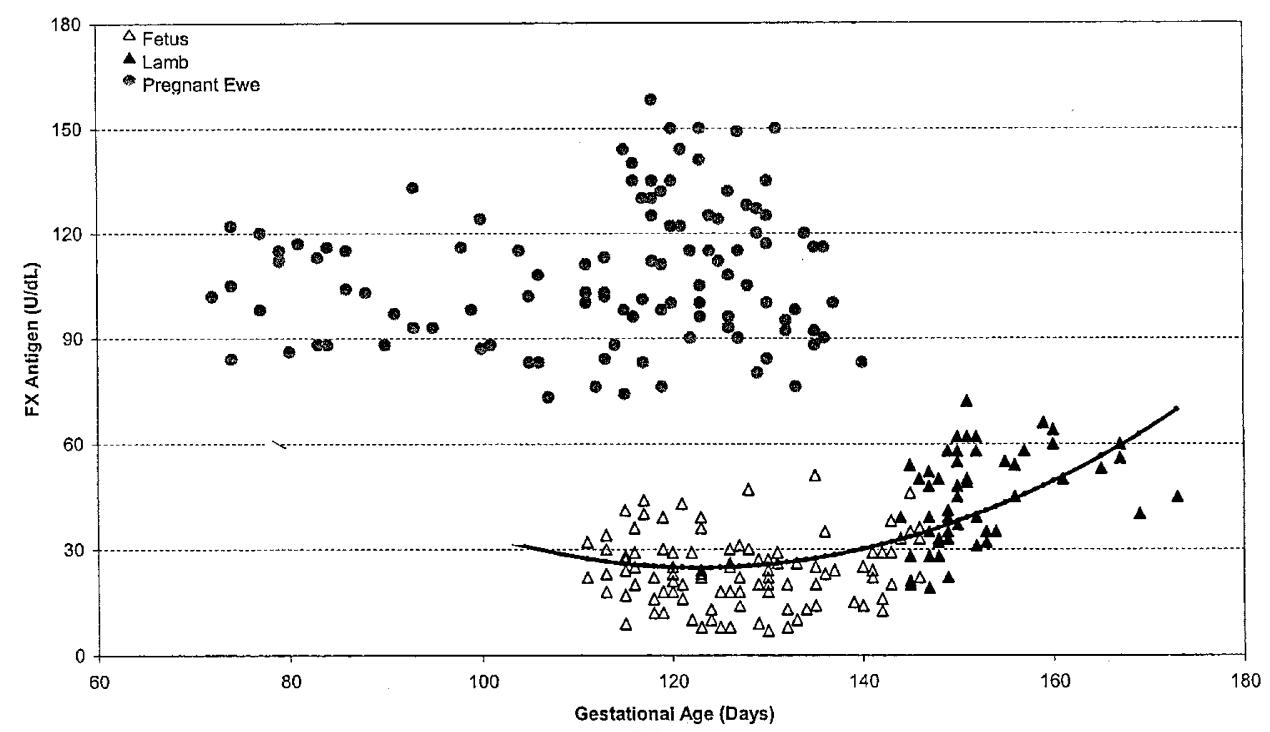

Figure 3. Factor $\mathrm{X}$ antigen in normal ovine fetuses, lambs, and ewes. Plasma concentration of FX in the ovine fetus, lamb, and pregnant ewe during gestation and postnatal development. Filled circles depict values in ewes; open triangles depict ovine fetal values; and filled triangles represent neonatal lambs after spontaneous delivery at term. Plasma concentration of fetal and neonatal FX antigen shows a gestational pattern similar to PS. The solid line represents the equation for the model of ovine fetal and lamb FX concentration relative to gestational age. Values in pregnant ewes do not change during gestation.

to gestational age, the fetal and lamb FX antigen values once again fit a model with both linear $(p<0.0001)$ and quadratic $(p<0.0001)$ components. The model showed a slight decrease in FX antigen from 110 to $130 \mathrm{~d}$ gestation and a significant increase that began just before and continued after birth. None of the samples in this study showed lamb levels of FX antigen reaching the maternal range.

Antithrombin. Figure 4 shows levels of AT activity in ovine fetuses and ewes as a function of postconceptional age. AT activity levels were available only for fetuses and ewes. The mean fetal and maternal AT activity levels were statistically significantly different $(p<0.0001)$. The mean AT activity levels were 84.2 U/dL among fetuses and 103.4 U/dL for ewes. The model of gestational age showed that the AT data had only a linear component $(p=0.0277)$. The samples showed a continual increase in AT activity levels from 70 to $145 \mathrm{~d}$ gestation. Beyond $115 \mathrm{~d}$ gestation, many of the fetal values fell within the maternal range.

Hepatic mRNA abundance for PC, PS, and AT. Figures 5-7 display fetal and lamb hepatic abundance of mRNA for PC, PS, and AT, respectively, in hepatic samples from 31 fetal and neonatal sheep and 10 ewes. Similar to the PC antigen model, the model of PC mRNA abundance and gestational age had both linear $(p=0.0120)$ and quadratic $(p=0.0027)$

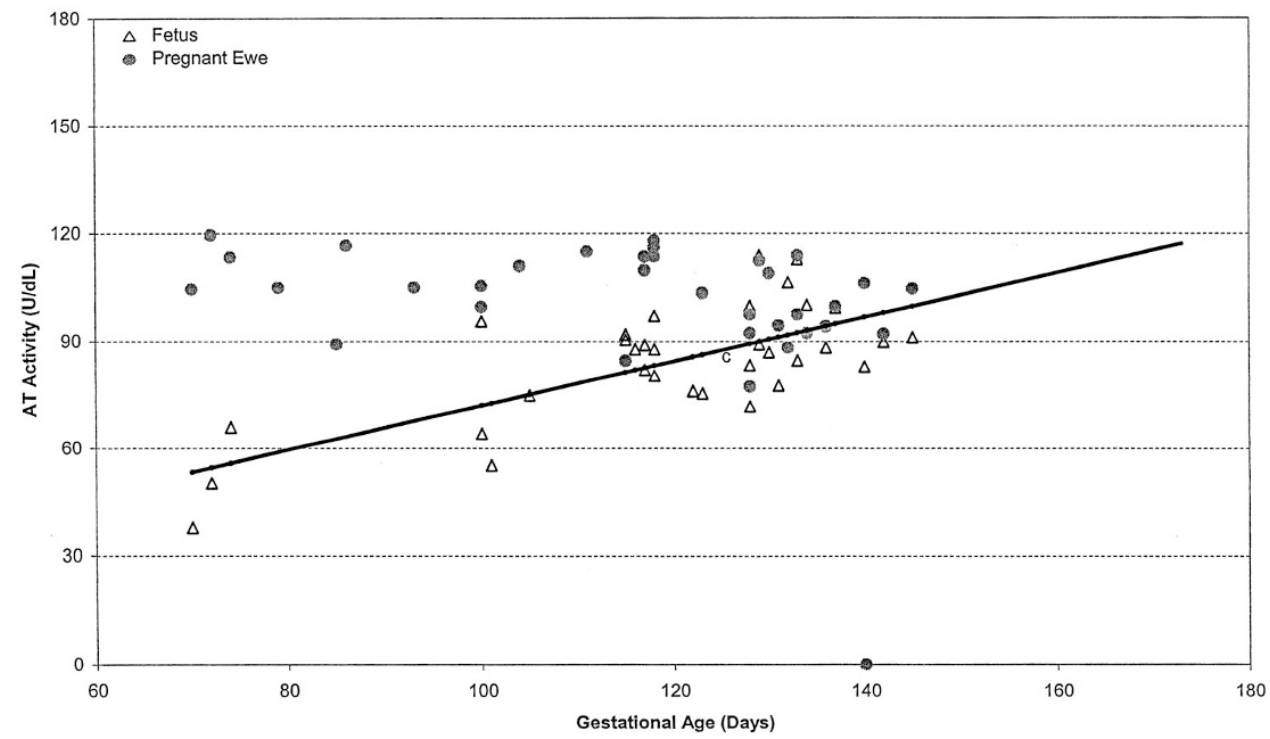

Figure 4. Antithrombin activity in normal ovine fetuses, lambs, and ewes. Plasma concentration of AT in the ovine fetus, lamb, and pregnant ewe during gestation and postnatal development. Filled circles depict values in ewes; open triangles depict ovine fetal values. Plasma concentration of fetal AT antigen shows consistent linear increases throughout gestation until achievement of adult values before term. The solid line represents the equation for the model of ovine fetal and lamb AT concentration relative to gestational age. Values in pregnant ewes do not change during gestation. 


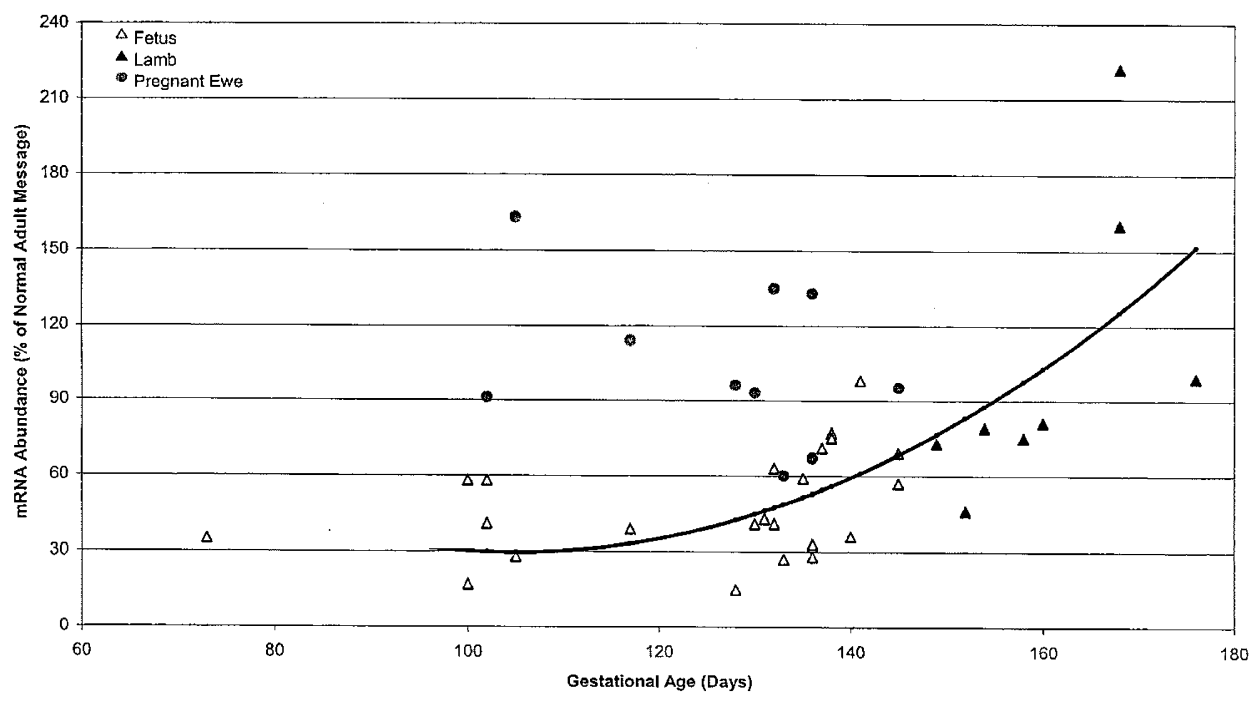

Figure 5. Expression of mRNA for protein $\mathrm{C}$ during gestation. Hepatic abundance of mRNA for PC in the ovine fetus, lamb, and pregnant ewe. Filled circles depict values in ewes; open triangles depict ovine fetal values; and filled triangles represent neonatal lambs after spontaneous delivery at term. Fetal and neonatal PC mRNA shows gestational dependence. The solid line represents the equation for the model of ovine fetal and lamb hepatic PC mRNA abundance relative to gestational age.

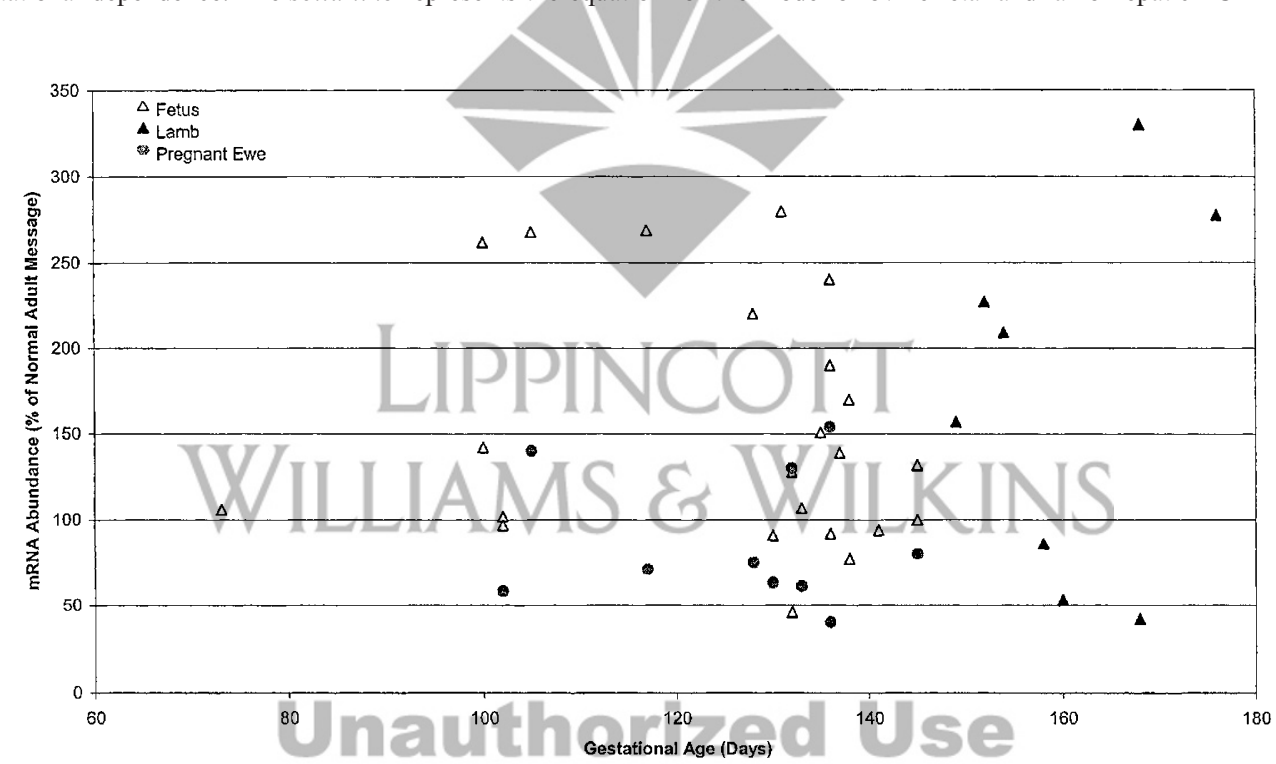

Figure 6. Expression of mRNA for protein S during gestation. Hepatic abundance of mRNA for PS in the ovine fetus, lamb, and pregnant ewe. Filled circles depict fetal values in ewes; open triangles depict ovine fetal values; and filled triangles represent neonatal lambs after sponotaneous delivery at term. Fetal and neonatal PS mRNA is elevated relative to the pregnant ewe and shows no relationship to gestational age.

components. There was not a statistically significant relationship between gestational age and mRNA abundance for PS or AT.

\section{DISCUSSION}

The human preterm and term neonates show an increased predisposition to thrombosis compared with the older infant and child (8). The increased incidence of thrombosis in the neonatal period has been ascribed to lower plasma concentrations of coagulation regulatory proteins secondary to physiologic immaturity.

Sheep have been used to model ontogeny of procoagulant proteins under conditions mimicking normal and pathologic states common to human infants $(20-22,25-29)$. In the studies presented in this article, the chronically catheterized fetal ovine model was used to investigate the development of various coagulation regulatory proteins from mid-gestation through the neonatal period. Surprisingly, we found that the plasma concentrations of PC at mid-gestation and at $3 \mathrm{wk}$ postnatal age were nearly the same. We noted a slight but statistically significant decrease in PC concentration from $100 \mathrm{~d}$ gestation to just before delivery at term, with a slow rise subsequently. Similar patterns were found for vitamin K-dependent FX. Kisker et al. (26) studied the development of procoagulant proteins in the ovine fetus using functional clotting assays and reported consistent linear increases throughout gestation for procoagulant factors V, VIII, XI, XII, and XIII. Data displayed in this manuscript showed decreases in functional activities of prothrombin, factor VII, and fibrinogen during the middle of the third trimester (26). Graphed data regarding FX in Kisker's 


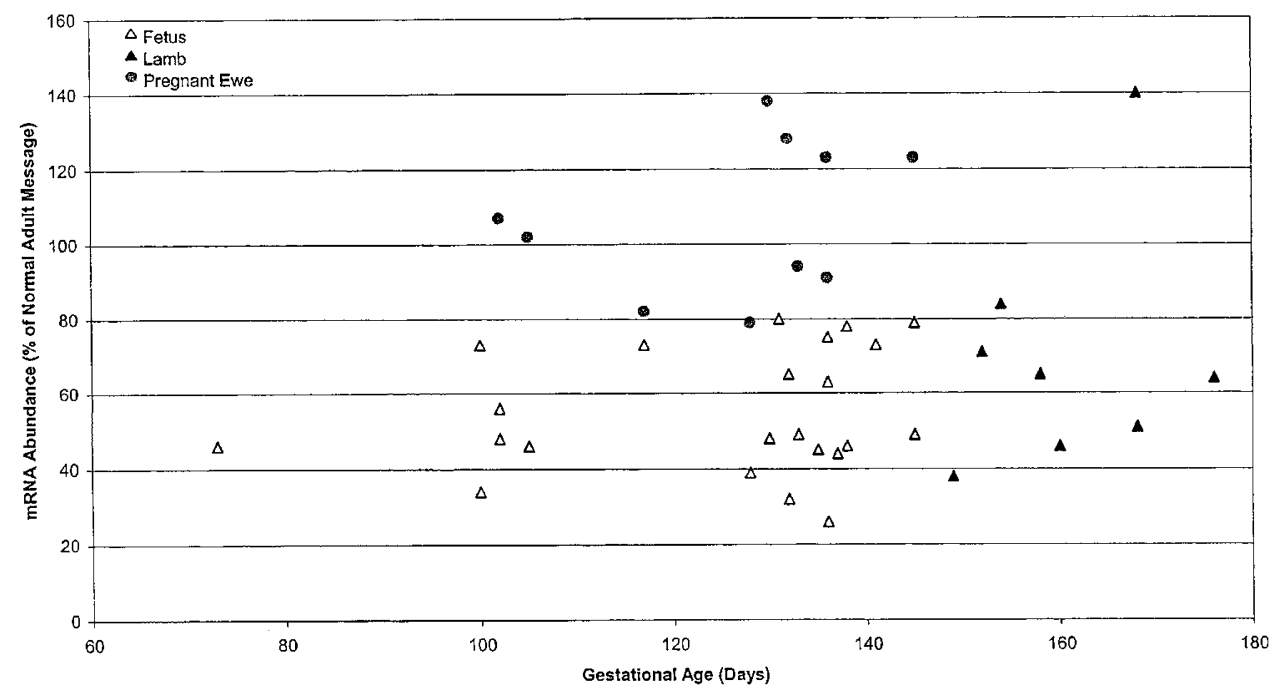

Figure 7. Expression of mRNA for antithrombin during gestation. Hepatic abundance of mRNA for AT in the ovine fetus, lamb, and pregnant ewe. Filled circles depict values in ewes; open triangles depict ovine fetal values; and filled triangles represent neonatal lambs after spontaneous delivery at term. Fetal and neonatal AT mRNA is decreased relative to the pregnant ewe and shows no relationship to gestational age.

report did not show a decrease in FX during fetal development, but analysis of the data points was not reported or discussed (26). We found a subtle but mathematically similar pattern of fetal plasma development for ovine procoagulant FX. Although our model is suggestive, more data are needed during early gestation to substantiate this observation. A crosssectional study of human fetal coagulation proteins showed early expression and delayed development of several coagulation proteins, especially prothrombin, factors IX and XI,PC, and PS. Factors V, VIII, and XII and AT showed continuous linear increases similar to the ovine model (3). The human fetal data were not modeled mathematically.

Total PS antigen was measured in this study. Free PS comprises the PS compartment not bound to C4b-binding protein. In the fetal blood sampling study of Moalic et al. (30), C4b-binding protein in the human fetus ranged from $1.8 \%$ at $19-23$ wk gestation to $9.3 \%$ at $30-38$ wk gestation. As there is very little C4b-binding protein, it can be assumed that essentially all the PS is in the free form.

We showed a characteristic pattern of fetal development of coagulation proteins related to vitamin $\mathrm{K}$ dependence. However, this relationship is not exclusive to vitamin K-dependent proteins, as Kisker et al. (26) found this pattern for ovine fibrinogen and Reverdiau-Moalic et al. (3) determined similar fetal development for human factor XI.

We showed a comparable developmental pattern for vitamin $\mathrm{K}$-dependent regulatory PC and total PS, but not for vitamin $\mathrm{K}$-independent AT. In addition, we compared plasma results with abundance of hepatic mRNA for these proteins in the fetal lamb and pregnant ewe and found that decreases in plasma concentration of vitamin K-dependent proteins contrasted to relatively increased abundance of hepatic mRNA. Although we did not normalize the fetal liver data to account for hematopoietic cells that occupy hepatic mass, such correction would have magnified the increase in relative abundance of fetal mRNA for vitamin K-dependent coagulation proteins. Abundance of hepatic mRNA for PS was shown to be substantially higher than the maternal values in most samples throughout gestation. In contrast, nearly all of the fetal and lamb values of PC and AT hepatic mRNA abundance were below the maternal values. It is noted that late in the third trimester and during the peripartum period, abundance of mRNA for PC increased without a concordant increase in plasma PC concentration. The development of PC may follow a course similar to that of PS but with a later time to maturation. Relative abundance of mRNA for AT was shown to be equal to or less than the corresponding plasma concentrations for gestational age, whereas mRNA abundance for PC and PS was consistently higher than the plasma concentrations at the same gestational age.

Data regarding expression of procoagulant proteins during fetal development have been recently reviewed $(3,31)$. The regulatory mechanisms are not completely understood. Plasma concentrations of most plasma proteins show continuous increases over time until the adult level is achieved and maintained. The development of ovine factors V, VIII, XI, XII, XIII, and AT fits this pattern. In addition, specific inducers of protein synthesis also are known. For example, vitamin Kdependent factor IX is known to have an androgen-responsive regulatory element (32). The onset of puberty or treatment with androgens results in a striking increase in factor IX concentration in individuals with the factor IX Leyden mutation, a form of hemophilia B known to result from mutations in promoter sequences that interfere with binding of critical transcription factors $(32,33)$. In addition, increases in corticosteroids around the time of human birth promote maturation of a number of proteins (34). Indeed, Kisker et al. (35) showed increases in factors II, V, VII, and X in the fetal lamb after hydrocortisone infusions into the lamb or $\beta$-methasone treatment given to the ewe. It is tempting to speculate that steroid hormones play a role in the physiologic regulation of perinatal and later developmental changes in coagulation proteins.

Postnatal synthesis of most hepatic proteins is regulated by rate of transcription (36). Hepatic protein synthesis has been 
estimated by determination of abundance of mRNA for the protein of interest in relation to other proteins whose expression is known to be independent of gestational age. In addition, expression profiles of active genes have been determined by collection of sequences with a 3'-directed DNA library that mirrors the composition of the mRNA population. Such studies have demonstrated that synthesis of coagulation proteins is among the most active in the fetus after production of plasma proteins such as albumin (37). Employing a methodology termed differential display reverse transcriptase- $P C R$, it has been shown that, in contrast to postnatal hepatic protein synthesis, approximately $99 \%$ of hepatic genes expressed during fetal development are not transcriptionally regulated, but most likely controlled at the level of translation (38). Hassan et al. (39) demonstrated that by five weeks of gestation mRNA and intracellular proteins for coagulation factors VII, VIII, IX, X, fibrinogen, PC, and AT could be detected in hepatic cells of human embryos. Between 5 and 10 wk of fetal development, most coagulation mRNA increased from $30 \%$ to $50 \%$ of the normal adult level (39). In this study, mRNA abundance for FX was equal to abundance in adult liver during the first trimester of gestation; intracellular concentration of FX in the hepatocyte was greater than that found in adult livers at this same time. Adsorption studies using barium citrate were consistent with intracellular $\gamma$-carboxylation of hepatic FX. In contrast to cellular results, concomitant plasma concentration of FX antigen was $20-40 \%$ of normal adult values, suggesting a block in FX secretion.

Regulation of vitamin K-dependent proteins may be unique. Karpatkin et al. $(40,41)$ documented expression of fetal hepatic mRNA for rabbit prothrombin/equal to or greater than expression in adult liver while plasma concentrations of prothrombin remained low, similar to our findings for PS and our perinatal results for $\mathrm{PC}$ as well as the $\mathrm{FX}$ results of Hassan et al. (39). The discordance between relative abundance of mRNA for vitamin K-dependent proteins and plasma concentrations supports that regulation is not at the level of gene transcription. Other possible explanations for the observed phenomena include decreased mRNA translation, ineffective protein synthesis, decreased intracellular protein stability, decreased protein secretion from the cell, secretion of unstable proteins with accelerated plasma elimination, or a nonspecific increase in protein catabolism.

PC undergoes complex post-translational modification including glycosylation, vitamin K-dependent $\gamma$-carboxylation, and $\beta$-hydroxylation. We previously reported increased $\mathrm{N}$ linked glycosylation of fetal ovine PC (21). Fetal fibrinogen is known to contain increased sialic acid, mannose, and phosphate relative to the adult molecular form (42). It is possible that altered fetal glycosylation contributes to accelerated plasma elimination of PC and other vitamin K-dependent proteins. Andrew et al. (43) reported increased plasma elimination of both fetal and adult fibrinogen in the healthy newborn lamb, suggesting accelerated nonspecific protein turnover in the fetus. Karpatkin et al. (31), however, were unable to detect any difference in plasma elimination of prothrombin in the newborn versus adult rabbit pup.
Vitamin $\mathrm{K}$ inhibition by warfarin has been shown to decrease protein antigen concentrations of dependent proteins in the plasma, as well as to result in dysfunctional molecules, suggesting a role of vitamin $\mathrm{K}$ in the regulation of protein synthesis (44-47). Experiments using HepG2 cells in culture demonstrated prothrombin secretion from the cell increased up to $100 \%$ and total prothrombin synthesis increased by $50 \%$ in the presence of excessive vitamin K1 (48). Secretion of prothrombin decreased by $19 \%$ after warfarin exposure in this model. However, the total amount of prothrombin mRNA was unchanged by either vitamin K1 or warfarin exposure. These and other data suggest that vitamin $\mathrm{K}$ is not directly related to transcription, but secretion of prothrombin and other vitamin $\mathrm{K}$-dependent proteins from the hepatocyte is linked to conformational changes that occur with $\gamma$-carboxylation and is decreased in vitamin $\mathrm{K}$ deficiency states (45-50).

The placenta maintains a steep gradient of vitamin $\mathrm{K}$ during gestation, with fetal levels approximately one-10th that of maternal $(51,52)$. Evidence for vitamin $\mathrm{K}$ deficiency at birth has been reported by many authors $(52,53)$. It has been speculated that high concentrations of vitamin $\mathrm{K}$ promote mutagenesis of DNA in vitro, and low levels of vitamin $\mathrm{K}$ are maintained during fetal development to diminish mutagenic risk in rapidly proliferating cells (54). Although we were unable to detect noncarboxylated PC in the subset of ovine fetuses studied, our assay may have been insensitive to partially carboxylated PC molecules. It is possible that diminished availability of hepatic vitamin $\mathrm{K}$ is an important physiologic regulator of plasma protein secretion in the ontogeny of the vitamin K-dependent proteins. Further studies are required to explore this possibility.

The current data support that vitamin K-dependent coagulation proteins, as a group, are characterized by early appearance and delayed fetal maturation of plasma concentration with physiologic hepatic regulation at a level beyond gene transcription. This pattern of ontogeny of plasma concentration of ovine vitamin K-dependent proteins is shared only by fibrinogen. Developmental rises during later gestation and perinatally are preceded by increased abundance of mRNA, suggesting altered translation, processing, secretion, or plasma half-life of these proteins. There is mounting evidence for a significant role of diminished secretion from the hepatocyte. The longest and most exaggerated delay is found in $\mathrm{PC}$; this delay should account, at least in part, for the severe PC deficiency found in sick preterm infants and may predispose the newborn infant to thrombosis.

Acknowledgments. The authors thank Daren Jacobson for performance of protein $\mathrm{S}$ and factor $\mathrm{X}$ assays and Dr. William E. Hathaway for his thoughtful review of the manuscript.

\section{REFERENCES}

1. Manco-Johnson M, Nuss R 2000 Hemostasis in the neonate. Neoreviews 1:e191e195

2. Hathaway WE, Bonnar J 1987 Hemostatic disorders of the pregnant woman and newborn infant. Elsevier Science Publishing Company, New York, pp 57-75

3. Reverdiau-Moalic P, Delahousse B, Body G, Bardos P, Leroy J, Gruel Y 1996 Evolution of blood coagulation activators and inhibitors in the healthy human fetus. Blood 88:900-906 
4. Nardi M, Karpatkin M 1986 Prothrombin and protein C in early childhood: normal adult levels are not achieved until the fourth year of life. J Pediatr 109:843-845

5. Andrew M, Paes B, Johnston M 1990 Development of the haemostatic system in the neonate and young infant. Am J Pediatr Hematol Oncol 12:95-104

6. Manco-Johnson MJ, Marlar RA, Jacobson LJ, Hays T, Warady BA 1988 Severe protein $\mathrm{C}$ deficiency in newborn infants. J Pediatr 113:359-363

7. Manco-Johnson MJ, Abshire TC, Jacobson LJ, Marlar RA 1991 Severe neonatal protein C deficiency: prevalence and thrombotic risk. J Pediatr 119:793-98

8. Andrew ME, Monagle P, deVeber G, Chan AKC 2001 Thromboembolic disease and antithrombotic therapy in newborns. Hematology (Am Soc Hematol Educ Program) Jan:358-374

9. Clauss LH, Comp PC 1986 The regulation of hemostasis:the protein C system. N Engl J Med 314:1298-1304

10. Marlar RA, Montgomery RR, Broekmans AW 1989 Diagnosis and treatment of homozygous protein C deficiency. J Pediatr 114:528-534

11. Hartman KR, Manco-Johnson M, Rawlings JS, Bower DJ, Marlar RA 1989 Homozygous protein $\mathrm{C}$ deficiency: early treatment with warfarin. Am J Pediatr Hematol Oncol 11:395-401

12. Rosenberg RD, Damus PS 1973 The purification and mechanism of action of human antithrombin-heparin cofactor. J Biol Chem 248:6490-6505

13. McDonald MM, Hathaway WE, Reeve EB, Leonard BD 1982 Biochemical and functional study of antithrombin III in newborn infants. Thromb Haemost 47:56-58

14. McDonald MM, Hathaway WE 1982 Anticoagulant therapy by continuous heparinization in newborn and older infants. J Pediatr 101:451-457

15. McDonald MM, Jacobson LJ, Hay WW, Hathaway WE 1981 Heparin clearance in the newborn. Pediatr Res 15:1015-1018

16. Manco-Johnson MJ 1989 Neonatal antithrombin III deficiency. Am J Med 87:49S-52S

17. Ishiguro K, Kojima T, Kadomatsu K, Nakayama Y, Takagi A, Suzuki M, Takeda N, Ito M, Yamamoto K, Matsushita T, Kusugami K, Muramatsu T, Saito H 2000 Complete antithrombin deficiency in mice results in embryonic lethality. J Clin Inves 106:873-878

18. Sanchez J, Velasco F, Alvarez R, Roman J, Torres A 1996 Aortic thrombosis in neonate with hereditary antithrombin III deficiency: successful outcome with thrombolytic and replacement treatment. Acta Paediatr 85:245-247

19. Jochmans K, Lissens W, Vervoort R, Peeters S, De Waele M, Liebaers I 1994 Antithrombin-Gly 424 Arg: a novel point mutation responsible for type 1 antithrombin deficiency and neonatal thrombosis. Blood 83:146-151

20. Kisker CT 1987 The animal models for hemorrhage and thrombosis in the neonate. Thromb Haemost 57:118-122

21. Manco-Johnson MJ, Spedale S, Peters M, Townsend SF, Jacobson LJ, Christian J, Krugman SD, Hay WW, Sparks JW 1995 Identification of a unique form of protein $\mathrm{C}$ in the ovine fetus: developmentally linked transition to the adult form. Pediatr Res 37:365-372

22. Manco-Johnson MJ, Carver T, Jacobson LJ, Townsend SF, Hay WW 1994 Hyper glycemia-induced hyperinsulinemia decreases maternal and fetal plasma protein C concentration during ovine gestation. Pediatr Res 36:293-299

23. Baker DC, Ropbbe SL, Jacobson LJ, Manco-Johnson MJ, Holler L, Lefkowitz J 1999 Hereditary deficiency of vitamin-K-dependent coagulation factors in Rambouille sheep. Blood Coagul Fibrinolysis 10:75-80

24. Chomczynski P, Sacchi N 1987 Single step method of RNA isolation by acid guanidium thiocyanate-phenol-chloroform extraction. Anal Biochem 1162:156-159

25. Reynolds ML, Evans CAN, Reynolds EOR, Saunders NR, Durbin GM, Wigglesworth JS 1979 Intracranial haemorrhage in the preterm sheep fetus. Early Hum Dev 3:163-186

26. Kisker CT, Robillard JE, Clarke W 1981 Development of blood coagulation-a fetal lamb model. Pediatr Res 15:1045-1050

27. Kisker CT, Robillard JE, Clarke W 1982 Blood coagulation changes after hypoxemia: a fetal lamb model. Pediatr Res 16:8-12
Kisker CT, Robillard JE, Clarke W 1982 Blood coagulation changes following

8. Kisker CT, Robillard JE, Clarke W 1982 Blood coagulation changes following
hypoxemia in the near-term fetal lamb. Pediatr Res 16:732-739 hypoxemia in the near-term fetal lamb. Pediatr Res 16:732-739 29. Kisker CT, Bohlken DP, Clarke WR 1985 Effects of acidosis on fetal and maternal 53 . blood coagulation: a fetal lamb model. Pediatr Res 19:78-82

30. Moalic P, Gruel Y, Body G, Foloppe P, Delahousse B, LeRoy J 1988 Levels and plasma distribution of free and $\mathrm{C} 4 \mathrm{~b}-\mathrm{BP}$-bound protein $\mathrm{S}$ in human fetuses and full-term newborns. Thromb Res 49:471-480
31. Karpatkin M, Lee M, Cohen L, McKinnell J, Nardi M 2000 Sythesis of coagulation proteins in the fetus and neonate. J Pediatr Hematol Oncol 22:276-280

32. Reijnen MJ, Peerlinck K, Maasdam D, Bertina RM, Reitsma PH 1993 Hemophilia B Leyden: substitution of thymine for guanine at position -21 results in a disruption of a hepatocyte nuclear factor binding site in the factor IX promoter. Blood 82:151-158

33. Boccia LM, Lillicrap D, Newcombe K, Mueller CR 1996 Binding of the Ets factor GA-binding protein to an upstream site in the factor IX promoter is a critical event in transactivation. Mol Cell Biol 16:1929-1935

34. Avery ME 1975 Pharmacologic approach to the acceleration of fetal lung maturation. Br Med Bull 31:13-17

35. Kisker CT, Robillard JE, Bohlken DP 1983 Glucocorticoid stimulation of blood coagulation factor activities in the fetal lamb. J Lab Clin Med 101:569-575

36. Xanthopoulos KG, Mirkovitch J 1993 Gene regulation in rodent hepatocytes during development, differentiation and disease. Eur J Biochem 216:353-360

37. Kawamoto S, MatsumotoY, Miuno K, Okubo K, Matsubara K 1996 Expression profiles of active genes in human and mouse livers. Gene 174:151-158

38. Malhotra K, Luehrsen KR, Costello LL, Raich TJ, Sim K, Foltz L, Davidson S, Xu H, Chen A, Yamanishi DT, Lindemann GW, Cain CA, Madlansacay MR, Hashima SM, Pham TL, Mahoney W, Schueler PA 1999 Identification of differentially expressed mRNAs in human liver across gestation. Nucleic Acids Res 27:839-847

39. Hassan HJ, Leonardi A, Chelucci C, Mattia G, Macioce G, Guerriero R, Russo G, Mannucci PM, Peschle C 1990 Blood coagulation factors in human embryonic-fetal development: preferential expression of the FVII/tissue factor pathway. Blood 76:1158-1164

40. Karpatkin M, Blei F, Hurlet A, Greco A, Tang Z 1991 Prothrombin expression in the adult and fetal rabbit liver. Pediatr Res 30:266-269

41. Cohen L, McKinnell J, Puglisi V, Greco A, Nardi M, Lee M, Karpatkin M 1997 Prothrombin synthesis in the adult and fetal liver. Thromb Haemost 78:1468-1472

42. Francis JL, Armstrong DJ 1982 Sialic acid and enzymatic desialation of cord blood fibrinogen. Haemostasis 11:223-228

43. Andrew M, Mitchell L, Berry LR, Schmidt B, Hatton MW 1998 Fibrinogen has a rapid turnover in the healthy newborn lamb. Pediatr Res 23:249-252

44. Thompson AR 1977 Factor IX antigen by radioimmunoassay. Abnormal factor IX protein in patients on warfarin therapy and with hemophilia B. J Clin Invest 59:900-910

45. Vigano S, Mannucci PM, Solinas S, Bottasso B, Mariani G 1984 Decrease in protein $\mathrm{C}$ antigen and formation of an abnormal protein soon after starting oral anticoagulant therapy. Br J Haematol 57:213-220

46. Takahashi H, Hanano M, Hayashi S, Arai Y, Yoshino N, Takakuwa E, Tatewaki W, Nagayama R, Takizawa S, Shibata A 1986 Plasma levels of protein C and vitamin $\mathrm{K}$-dependent coagulation factors in patients on long-term oral anticoagulant therapy. Tohoku J Exp Med 149:351-357

47. Weiss P, Soff GA, Halkin H, Seligsohn U 1987 Decline of proteins C and S and factors II, VII, IX and X during initiation of warfarin therapy. Thromb Res 45:783790

48. Jamison CS, Burkey BF, Degen SJ 1992 The effects of vitamin K1 and warfarin on prothrombin expression in human hepatoblastoma (HepG2) cells. Thromb Haemost $68: 40-47$

49. Vermeer C 1984 The vitamin K-dependent carboxylation reaction. Mol Cell Biochem $61: 17-35$

50. Wallin R, Stanton C, Hutson SM 1993 Intracellular maturation of the gammacarboxyglutamic acid region in prothrombin coincides with release of the propeptide. Biochem J 291:723-727

51. Shearer MJ, Rahim S, Barkhan P, Stimmler L 1982 Plasma vitamin K1 in mothers and their newborn babies. Lancet 2:460-463

52. Mandelbrot L, Guillaumont M, Leclercq M, Lefrere JJ, Gozin D, Daffos F, Forestier F 1988 Placental transfer of vitamin K1 and its implications in fetal hemostasis. Thromb Haemost 60:39-43

53. Shapiro AD, Jacobson LJ, Armon ME, Manco-Johnson MJ, Hulac P, Lane P, Hathaway WE 1986 Vitamin K deficiency in the newborn infant: prevalence and perinatal risk factors. J Pediatr 109:675-680

54. Israels LG, Israels ED 1995 Observations on vitamin K deficiency in the fetus and newborn: has nature made a mistake? Semin Thromb Hemost 21:357-363 